\title{
Precocious Pseudo-puberty in a Two-year-old Girl, Presenting with Bilateral Ovarian Enlargement and Progressing to Unilateral Juvenile Granulosa Cell Tumour
}

\author{
(D) Hager Barakizou1, (D) Souha Gannouni1, (D) Thouraya Kamoun², (D) Muhammed Mehdi3, (D) Fernanda Amary4, (D) Zilla Huma4, \\ (i) Anne-Laure Todeschini5, (1) Reiner Veitia5, (1) Malcolm Donaldson6
}

${ }^{1}$ Military Hospital of Tunis, Clinic of Pediatric, Tunis, Tunisia

${ }^{2}$ Centre Hospitalo-Universitaire, Department of Pediatric, Sfax, Tunisia

${ }^{3}$ Glan Clwyd Hospital, Clinic of Pathology, Rhyl, United Kingdom

${ }^{4}$ Royal National Orthopaedic Hospital, London, United Kingdom

5 Université Paris-Saclay, Institut de Biologie François Jacob, Gif-sur-Yvette, France

GGlasgow University School of Medicine, Glasgow, United Kingdom

\section{What is already known on this topic?}

Causes of feminising precocious pseudo-puberty of ovarian origin include follicular cysts, McCune-Albright syndrome (MAS) and juvenile granulosa cell tumour (JGCT). MAS and JGCT are associated with mutations in the GNAS and AKT1 genes respectively, but GNAS mutations have also been found in JGCT. Ovarian involvement is usually unilateral in JGCT, and unilateral or bilateral in MAS.

\section{What this study adds?}

We present a case in which feminizing precocious pseudo-puberty was initially associated with bilaterally enlarged, cystic ovaries. Shortly after presentation, the signs of feminisation escalated and repeat imaging showed a histologically proven JGCT in one ovary, with return of the other ovary to normal. Although a molecular genetic cause has not yet been identified, with normal GNAS, AKT1 exon 3 and FOXL2 sequencing, this unique observation shows how a unilateral JGCT was preceded by enlargement and cystic change in both ovaries.

\begin{abstract}
Ovarian causes of precocious pseudo-puberty (PPP) include McCune-Albright syndrome (MAS) and juvenile granulosa cell tumour (JGCT). We describe a case of PPP in which bilateral ovarian enlargement with multiple cysts progressed to unilateral JGCT. A girl aged 2.17 years presented with three months of breast development, and rapid growth. Examination showed tall stature, height +2.6 standard deviations, Tanner stage B3P2A1. A single café au lait patch was noted. Bone age was advanced at 5 years. Pelvic ultrasound showed bilaterally enlarged ovaries (estimated volumes $76 \mathrm{~mL}$ on the left, $139 \mathrm{~mL}$ on the right), each containing multiple cysts. Luteinizing hormone (LH) and follicle stimulating hormone (FSH) values before/after gonadotrophin administration were 0.43/0.18 and $<0.1 /<0.1$ $\mathrm{mUI} / \mathrm{mL}$, serum estradiol $130 \mathrm{pg} / \mathrm{mL}$, (prepubertal range $<20 \mathrm{pg} / \mathrm{mL}$ ). PPP of ovarian origin was diagnosed, and tamoxifen 20 mg daily started. However, after only seven weeks height velocity escalated and breast development increased to B3-4 with menorrhagia. Basal/ stimulated LH and FSH were still suppressed at $0.13 / 0.25$ and $<0.1 /<0.1 \mathrm{mUI} / \mathrm{mL}$ and, serum estradiol $184 \mathrm{pg} / \mathrm{mL}$. Repeat imaging now showed normal right ovary (volume $1.8 \mathrm{~mL}$ ) and a large left-sided vascular solid/cystic ovarian tumour which was excised (weight $850 \mathrm{~g}$ ). Histology showed JGCT, International Federation of Gynecology and Obstetrics stage IA. DNA from tumour tissue showed no mutation in GNAS, exon 3 of AKT1 (which contains a mutational hotspot) or FOXL2. The observation that bilateral ovarian activity progressed to unilateral development of JGCT in this patient is novel. This case highlights current uncertainties in the ontology of JGCT, and its possible relationship with MAS.
\end{abstract}

Keywords: Feminizing precocious pseudo-puberty, ovary, juvenile granulosa cell tumour, McCune-Albright syndrome

Address for Correspondence: Malcolm Donaldson MD, Section of Child Health, Royal Hospital for Children, Glasgow, United Kingdom

Phone: + 441414515841 E-mail: malcolm.donaldson@glasgow.ac.uk ORCID: orcid.org/0000-0001-9563-8442

${ }^{\circ}$ Copyright 2022 by Turkish Pediatric Endocrinology and Diabetes Society

The Journal of Clinical Research in Pediatric Endocrinology published by Galenos Publishing House.
Conflict of interest: None declared Received: 08.02.2021 Accepted: 08.04.2021 


\section{Introduction}

Premature sexual development can be broadly divided into true, or central, precocious and early puberty arising from activation of the hypothalamo-pituitary axis; and precocious pseudo-puberty in which there is either autonomous secretion of sex steroids by the gonads or adrenal glands, or from exogenous sources (1).

Causes of ovarian precocious pseudo-puberty include autonomous follicular cysts, which are usually self-limiting (2), the McCune Albright syndrome (MAS), sex cord tumours arising from granulosa and thecal cells, and from germ cell tumours. MAS usually results from a somatic gain-offunction mutation in the GNAS1 gene which encodes the G-protein alpha subunit-GNAS, causing a mosaic pattern involvement of various tissues, particularly skin, bone and ovary (3). Principal features are café au lait patches, precocious pseudo-puberty due to ovarian involvement, and polyostotic fibrous dysplasia (4). Renal phosphate wasting may accompany the latter (5). Rarely, MAS occurs in association with Cushing syndrome (6), gigantism/ acromegaly (7) and hyperthyroidism (8). The diagnosis can be made clinically when there is multisystem involvement, but isolated monostotic bone lesions may require confirmation by histology and molecular analysis is indicated in atypical cases with single organ involvement (9).

Granulosa cell tumours belong to the group of sex cordgonadal stromal tumours and account for $5 \%$ of all malignant ovarian tumours (10). Adult granulosa cell tumours are caused by mutations in FOXL2, the gene encoding Forkhead box protein L2 (11), usually present after 30 years of age and account for $<1 \%$ of granulosa cell tumours in prepubertal children (12). Juvenile granulosa cell tumours (JGCT), which represent $5-12 \%$ of ovarian tumours in childhood, usually present before 30 years of age with feminizing precocious pseudo-puberty in children, disturbance of menstrual cycle with or without signs of hyperandrogenism in women, and abdominal mass at any age (13). In some cases, torsion of the annex or tumour rupture with haemo-peritonitis result in presentation with an acute abdomen. Biological markers, such as Inhibin B and Anti-Müllerian hormone levels are raised and are of value in tumour monitoring. JGCT has been associated in $60 \%$ of cases with mutations of the AKT1 gene, which encodes the RAC-alpha serine/threonineprotein kinase enzyme (14). Of note, GNAS mutations have been described in some cases of JGCT (15).

We present a case in which feminizing precocious pseudopuberty was associated with bilateral ovarian enlargement initially, but which then progressed to JGCT with normal appearances of the contralateral ovary.

\section{Clinical Assessment, Biochemical Investigations and Diagnostic Imaging}

These were carried out in the Military Hospital of Tunis. Height and weight were measured using standardized equipment, and values converted to standard deviations (SD) for corresponding ages using the normative French data of Sempe et al (16). Skeletal maturity ("bone age") was assessed by the method of Greulich et al (17). Luteinising hormone (LH) and follicle stimulating hormone (FSH) were sampled before and 15, 30 and 60 minutes after stimulation with $100 \mathrm{mcg}$ of luteinizing hormone (LH) releasing hormone (LHRH) and measured using chemiluminescence immunoassay (UniCel DxI 600 Access Immunoassay System, Beckmann Coulter International S.A., Nyon, Switzerland). Estradiol was measured using enzyme-linked fluorescent immunoassay (VIDAS, Biomérieux F-69280 Marcy l'Etoile, France). Laboratory reference ranges for $\mathrm{LH}$ during the follicular phase, mid-cycle, and luteal phase were 1-7, 6-73 and $0.5-10 \mathrm{mIU} / \mathrm{mL}$. For FSH the equivalent ranges were 3-8, 4-18 and 2-8 mIU/mL and for estradiol <266, 118-255, and $26-165 \mathrm{pg} / \mathrm{mL}$. For prepubertal girls, mean \pm SD for $\mathrm{LH}$ was $0.03 \pm 0.03 \mathrm{mIU} / \mathrm{mL}$ and for FSH $2.16 \pm 1.14 \mathrm{mIU} / \mathrm{mL}$. Prepubertal range for estradiol was $<20 \mathrm{pg} / \mathrm{mL}$. Limit of detection was $<0.1 \mathrm{mIU} / \mathrm{mL}$ for $\mathrm{LH}$ and FSH, and $<10 \mathrm{ng} /$ $\mathrm{mL}$ for estradiol.

Ultrasound imaging was carried out in the Radiology Department of the Military Hospital of Tunis using a General Electric Logiq S7 model (General Electric, Boston, MA 02210) featuring a 3.6-15 MHz transducer.

Magnetic resonance imaging (MRI) was carried out using a MRI MAGNETOM Verio-Siemens 3 Tesla scanner (Siemens, 80333 Munich, Germany). Since only two of three dimensions - length, width, and depth - were available for the initial ultrasound, approximate volumes were calculated using the prolate ellipsoid formula and assuming that width and depth were the same on the sagittal view and that length was at least the same as width and depth on the transverse view.

Bone imaging was carried out according to a standardised protocol using a gamma camera (Siemens, 80333 Munich, Germany), and scanning the whole skeleton two hours after injecting ${ }^{99}$ technetium-labelled hydroxylmethyl diphosphonate

\section{Tumour Histopathology, Immune Staining and Genetic Studies}

Paraffin blocks of tumour were sent first to the Royal National Orthopaedic Hospital in London where histopathology findings were corroborated and mutational analysis for GNAS1 were performed. DNA was successfully extracted, 
and the sample was tested for the hotspots R201H, R201C and Q227L, as previously described (18).

The paraffin blocks were then sent on to the François Jacob Institute of Biology in Paris, where mutational analysis of exon 3, a mutational 'hot spot' of the AKT1 gene, and FOXL2-C134W status were carried out. DNA was extracted from paraffin-embedded tumor material using xylene. Tissue was then rehydrated with successive baths of ethanol, then vortexed and centrifuged, and the supernatant removed. After futher ethanol rehydration steps, tissue was digested with proteinase $\mathrm{K}$ and DNA extraction performed with the Nucleospin DNA rapid Lyse kit (Macherey-Nagel, Allentown, PA 18109, United States). Given the poor quality of the DNA extracted from paraffin-embedded tissue, amplification of exon 3 of $A K T 1$ required a semi-nested polymerase chain reaction (PCR), using three primers. The central part of FOXL2 was amplified by conventional PCR. PCR was performed with the Herculase II Fusion DNA Polymerase (Agilent, Santa Clara, CA 95051 United States) according to the manufacturer protocol. Sanger sequencing was performed by Eurofins according to their in-house procedures.

Finally, since the original histology report from Tunisia had suggested the presence of Call-Exner bodies, which are associated with adult rather than JGCT, tissue was sent from Paris to the pathology department at Glan Clwyd Hospital in Wales, United Kingdom for further review.

\section{Case Report}

A girl was admitted, aged 2.17 years, for assessment of premature sexual development which took the form of rapid growth and breast development over a 3-month period.
Delivery was by caesarean section at 38 weeks of gestation, birth weight 3650 grams, birth length $50 \mathrm{~cm}$, head circumference $34.5 \mathrm{~cm}$. There was no relevant family history, and parents were unrelated. The mother's menarche was at 12 years.

On examination, the child was well, height $94 \mathrm{~cm}(+2.6$ $\mathrm{SD})$, weight $13.2 \mathrm{~kg}(+1 \mathrm{SD})$ compared with a mid-parental height of -0.4 SD (mother's height $160 \mathrm{~cm}$, father's height $174 \mathrm{~cm}$ ). Bone age was 5.0 years (chronological age 2.2 years). Pubertal stage according to Tanner was B3P2A1. The abdomen was supple and non-tender with no palpable masses. Skin examination showed a single café au lait patch situated on the antero-lateral border of the left thigh, $3 \mathrm{~cm}$ in its longest axis, with irregular outline. There were no lentigines, haemangiomas or subcutaneous tumours, no hepato-splenomegaly, and no bony tenderness or deformity.

Biochemical investigations before and after LHRH stimulation showed basal/peak LH values of 0.43/0.18 mUI/ $\mathrm{mL}$ and FSH values $<0.1 /<0.1 \mathrm{mUI} / \mathrm{mL}$. Serum estradiol was $130 \mathrm{pg} / \mathrm{mL}$, (prepubertal range $<20 \mathrm{pg} / \mathrm{mL}$ ).

Pelvic ultrasound examination showed uterine length of 3.6 $\mathrm{cm}$ with fundo-cervical ratio 1.3 and pubertal configuration, and $4 \mathrm{~mm}$ of endometrial thickness. The images of each ovary, recorded at the time of examination, are of relatively inferior quality but show enlargement with multiple cysts and echogenic stroma (Figures 1a, 1b). The left ovary measured $63 \times 48 \mathrm{~mm}$ in the sagittal plane, estimated volume $76 \mathrm{~mL}$, right ovary $66 \times 61 \mathrm{~mm}$ in the transverse plane, estimated volume $139 \mathrm{~mL}$. Each ovary contained both discrete and coalescent cysts (Figures 1a, 1b).

MAS was considered a possibility in the light of the pelvic ultrasound and skin findings. Further investigations to assess parathyroid, growth hormone $(\mathrm{GH})$, adrenal, thyroid

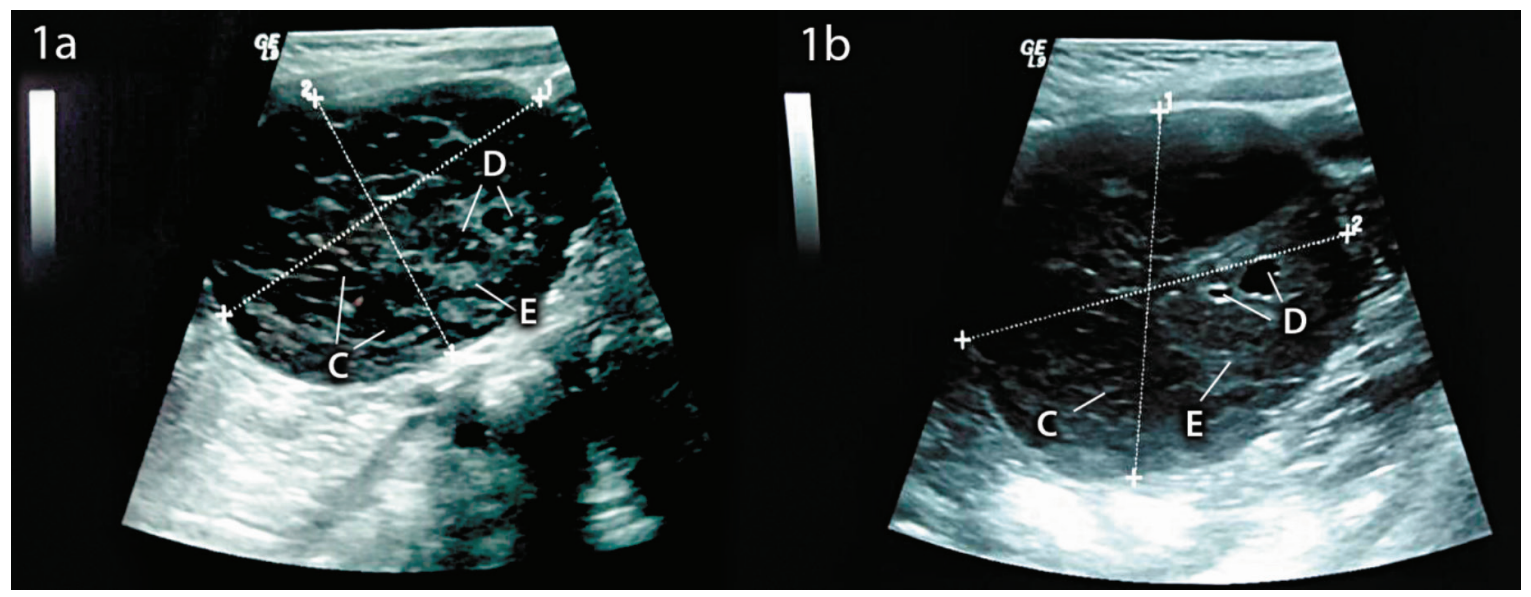

Figure 1. a, b) Ultrasound images of left (1a) and right (1b) ovaries in a 2-year-old girl with feminizing precocious pseudo-puberty and suppressed gonadotrophins. Both ovaries are very enlarged (see text) with echo-dense stroma. Both ovaries contain multiple cysts, some discrete and others coalescent as shown by the arrows 
and skeletal status were therefore carried out, with normal results: serum calcium $2.36 \mathrm{mmol} / \mathrm{L}$, phosphate $1.59 \mathrm{mmol} / \mathrm{L}$ (reference range 1.2-2.0 mmol/L), insulin-like growth factor 1 (IGF-1) $103 \mu \mathrm{g} / \mathrm{L}$ (age-related reference range 82-166 $\mu \mathrm{g} / \mathrm{L}$ ), urine free cortisol $160 \mathrm{nmol} / \mathrm{L}$ (reference range 100$300 \mathrm{nmoL} / 24$ hours), free thyroxine $13.5 \mathrm{pmol} / \mathrm{L}$, TSH 2.37 $\mu \mathrm{UI} / \mathrm{mL}$. Bone scintigraphy of the whole skeleton was also carried out to exclude fibrous dysplasia and no bony lesion was identified.

In view of the precocious pseudo-puberty, tamoxifen 20 mg oral daily was started at 2.3 years but after only seven weeks, aged 2.45 years the features of premature sexual development escalated with an increase in height of $4 \mathrm{~cm}$, progression of breast development, Tanner stage now B34P2A1, and development of menorrhagia. Bone age had advanced further to 6.5 years. A second LHRH test, carried out to exclude secondary activation of the hypothalamopituitary axis, still showed gonadotrophin suppression with basal/peak LH $0.13 / 0.25$ and FSH $<0.1 /<0.1 \mathrm{mUI} / \mathrm{mL}$. Serum estradiol was $184 \mathrm{pg} / \mathrm{mL}$.

Repeat pelvic ultrasound now demonstrated a left-sided vascular solid/cystic ovarian tumour measuring $10 \times 8 \times 6$ $\mathrm{cm}$ lying postero-lateral to the bladder. The right ovary was normal in appearance, volume $1.83 \mathrm{~mL}$.

The left ovarian mass was confirmed by MRI scan (Figure 2) which showed a well-defined solid-cystic abdominal-

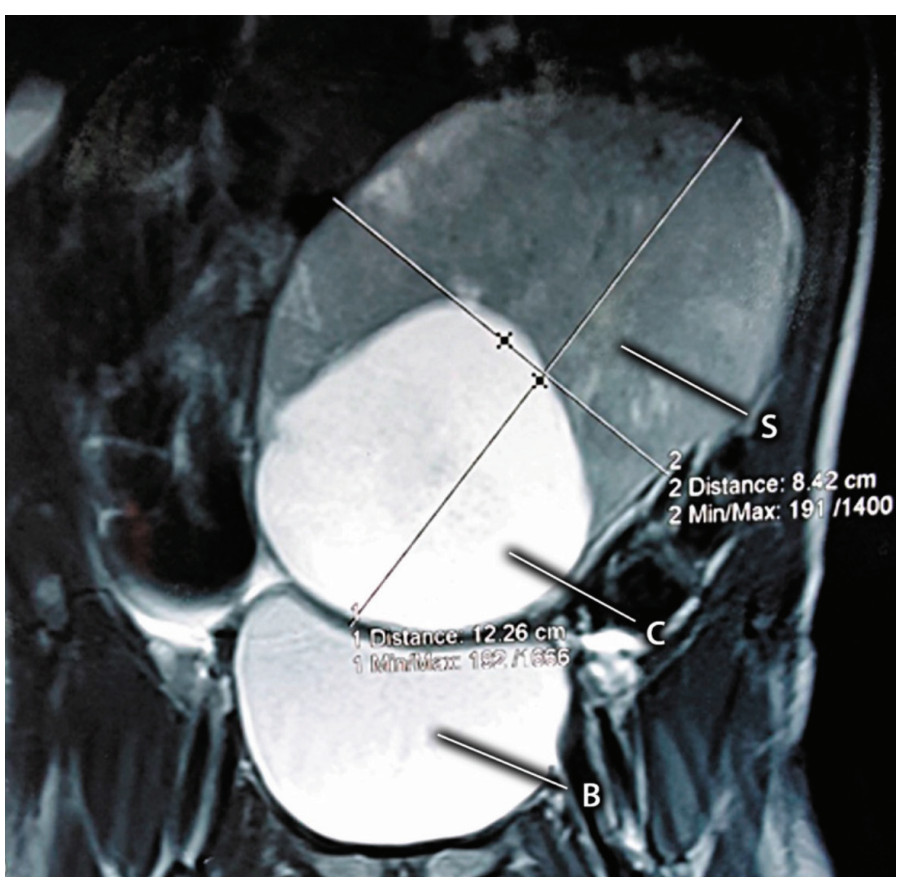

Figure 2. Magnetic resonance imaging of right ovary showing solid/cystic tumour, histology of which showed juvenile cell granulosa tumour

B: bladder, C: cystic tumour, S: solid tumour pelvic mass of left ovarian origin, measuring $12 \times 10 \times 5 \mathrm{~cm}$, extending to the aorta and kidney with no evidence of local invasion. The right ovary was normal. Tumour markers were normal: $\alpha$ feto-protein $4.2 \mathrm{ng} / \mathrm{mL}$ (reference range $<10 \mathrm{ng} /$ $\mathrm{mL}$ ), human chorionic gonadotrophin $<0$ (reference range $<2 \mathrm{ng} / \mathrm{mL}$ ), and ACE $2.3 \mathrm{ng} / \mathrm{mL}$ (reference range $<5 \mathrm{ng} /$ $\mathrm{mL}$ ). CA-125 was slightly raised at $43 \mathrm{IU} / \mathrm{mL}$ (reference range $<35 \mathrm{IU} / \mathrm{mL}$ ). Inhibin B assay was not available.

After a week, the child developed symptoms related to torsion of the ovarian annex, requiring urgent laparotomy with removal of left ovary and annexectomy. At surgery, the tumour capsule was intact, tumour weight $850 \mathrm{~g}$. No malignant cells were found on peritoneal lavage and there was no macroscopic evidence of infiltration of the capsule, and no spread to the fallopian tubes.

Histopathology review showed a tumour with nodular architecture, the nodules being encircled by fibrous tissue forming septae (Figure 3a). There were necrotic foci in some nodules (Figure 3b). High power imaging showed that the tumour cells had abundant pale eosinophilic cytoplasm, with oval, irregular vesicular nuclei, rarely showing nuclear grooves, and with rare mitoses (Figure 3c). Reticulin staining showed fibres surrounding groups of granulosa cells (Figure 3d). No follicles or pseudopapillary architecture was noted and no Call-Exner bodies were seen. Features of germ cell tumour or gonadoblastoma were not identified. There was no capsular infiltration.

Immunochemistry showed strongly positive staining for inhibin B but $\alpha$-fetoprotein and anti-CD30 were not detected. The findings were consistent with a JGCT, graded as International Federation of Gynecology and Obstetrics (FIGO) stage IA in view of its confinement within the tumour capsule. Post-operative progress showed immediate regression of the pubertal signs and metrorrhagia.

At review, aged 5.7 years, height was $113 \mathrm{~cm}$ (+ $0.9 \mathrm{SD})$, weight $17.2 \mathrm{~kg}$ (0 SD), pubertal stage B1P1A1, bone age 7.0 years. Basal gonadotrophins showed LH $2.49 \mathrm{mIU} / \mathrm{mL}$, FSH $2.52 \mathrm{mIU} / \mathrm{mL}$ and oestradiol $13 \mathrm{pg} / \mathrm{mL}$. Abdominal and pelvic ultrasound were normal.

Thereafter, the girl has remained prepubertal. At last review, aged 8.1 years, height was $125 \mathrm{~cm}(-0.53 \mathrm{SD})$, Tanner stage B1P1A1, bone age now only slightly advanced at 8.7 years. However, basal LH has continued to show mild elevation despite breast stage and estradiol levels remaining prepubertal. Thus LH/FSH and estradiol values at 6.5, 7.0 and 8.1 years were: $0.87 / 3.78 \mathrm{mIU} / \mathrm{mlL}$ and $11 \mathrm{pg} / \mathrm{mL}$, $1.24 / 1.62 \mathrm{mIU} / \mathrm{mlL}$ and $12 \mathrm{pg} / \mathrm{mL}$ and $1.46 / 5.66 \mathrm{mIU} / \mathrm{mL}$ and $13 \mathrm{pg} / \mathrm{mL}$, respectively. 
a)

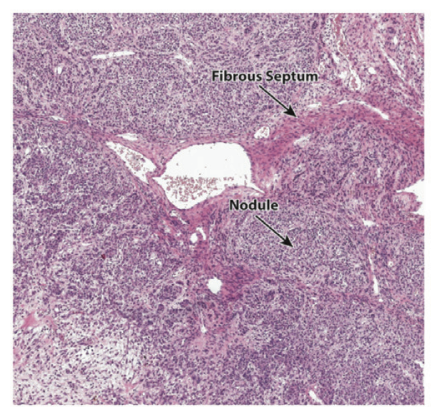

b)

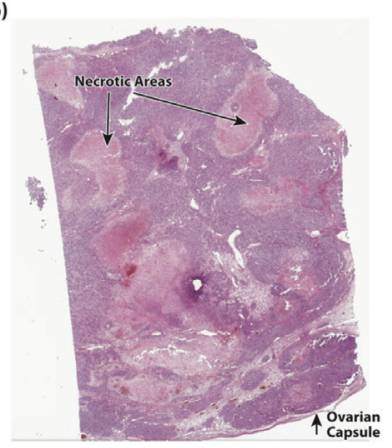

c)

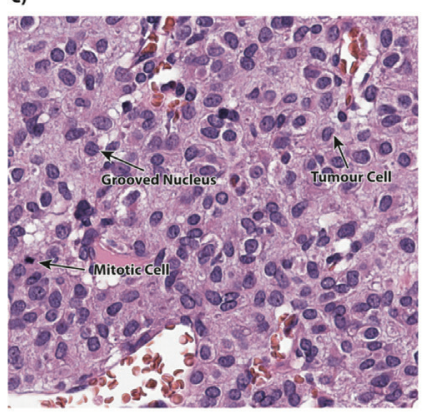

d)

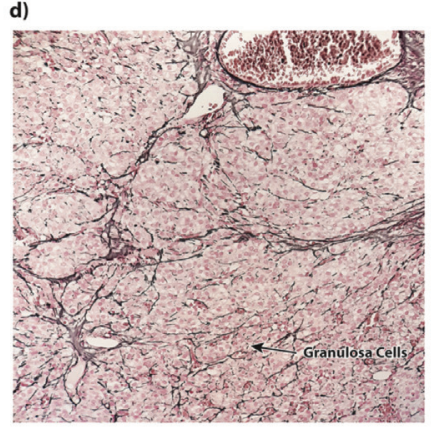

Figure 3. a, b, c, d) Histology of juvenile granulosa cell tumour with labelled features showing: a) low power haematoxylin and eosin (H\&E) image showing cellular neoplasm with nodules divided by fibrous septae; b) low power H\&E showing necrotic areas within some nodules and intact ovarian capsule; c) high power H\&E showing abundant eosinophilic cytoplasm with round to oval tumour cells with vesicular chromatin, only a few nuclei showing groove formation, and rare mitoses; and d) medium power reticulin stain showing fibres surrounding groups of granulosa cells

GNAS1 gene mutation analysis by PCR and restriction enzyme digestion of DNA extracted from paraffin blocks of the tumour was negative for the common hot-spot mutations (R201C, R201H and Q227L). Sequencing of exon 3 in the AKT1 gene in the tumour tissue did not show a somatic mutation. Finally, sequencing of FOXL2 was carried out to exclude an adult granulosa cell tumour, and the $\mathrm{C} 134 \mathrm{~W}$ FOXL2 pathogenic variant was not found.

\section{Discussion}

Although the feminising precocious pseudo-puberty in this case was clearly of ovarian origin, its precise aetiology remains unclear. At presentation with premature sexual development, the morphology of the ovaries reflected bilateral activity with cysts, gonadotrophin suppression and a single café au lait patch on the thigh. Although this pattern is evocative of MAS there were no other features of MAS, such as bony fibrous dysplasia, with no bony lesion being found on scintigraphy, no abnormality of

renal phosphate transport, no disturbance of the GH/IGF1 axis, Cushing syndrome, or hyperthyroidism. Moreover, the ovarian volumes-estimated at $76 \mathrm{~mL}$ on the left and $139 \mathrm{~mL}$ on the right-were extraordinarily large, far greater than in the study of eight patients with MAS described by Foster et al (19) in whom mean ovarian volumes overlapped with those seen in girls with central precocious puberty. Also, GNAS1 analysis in the tumour was negative. However, GNAS1 mutations are not found in the ovarian tissue of every patient with this MAS. It therefore remains possible that our patient has MAS and may show additional signs of this syndrome as she grows older although she remains well with no additional signs six years after initial presentation.

While it was not possible to diagnose MAS with certainty, it was clear that our patient had precocious pseudo-puberty of ovarian origin, as opposed to true precocious puberty, at presentation and she was therefore treated with tamoxifen, a medication which exerts an anti-estrogen effect through competitive inhibition of binding of estradiol with its receptors.

The clinical situation then changed dramatically in less than two months, with development of a large tumour in a single ovary. The tumour was limited to one side with intact and tumour-free capsule on the surface of the ovary. According to the FIGO classification this corresponds to stage IA, where the tumour is localized to the organ of origin. Histological review showed the tumour to be a granulosa cell tumour of juvenile type. In keeping with this, reticulin staining showed fibres surrounding groups of granulosa cells, contrasting with thecoma and fibroma tumours in which fibres surround individual granulosa cells. Moreover, Call-Exner bodies, which are a feature of adult granulosa cell tumour, were not present while mutational analysis of FOXL2 was negative. The diagnosis of JGCT is therefore secure.

Just as a diagnosis of MAS in our patient cannot be supported, neither can her case be fully explained by the diagnosis of unilateral JGCT since there was documented evidence of bilateral ovarian activity and enlargement on ultrasound at initial presentation. The present diagnosis therefore is purely descriptive - precocious pseudo-puberty of ovarian origin, with progression to JGCT-in which the underlying mechanism remains unclear. We speculate that some disorder of cell-signalling resulted initially in the bilateral ovarian enlargement with cyst formation, and that the cysts were estrogen-secreting. Following this, the process seems to have spontaneously resolved in one ovary, with transformation, perhaps involving one of the cysts, into JGCT. 
We believe that ours is a unique observation. Although bilateral JGCT has been reported (12), presentation with bilateral ovarian enlargement evolving towards unilateral regression and contralateral tumour formation has not. The clinical and pathological features of our case are consistent with previous reports, including the recent paper from Ye et al (20).

There is an intriguing overlap between MAS and JGCT. Mutational analysis using nested PCR is reported to have a $54 \%$ sensitivity for detecting a GNAS mutation in suspected MAS (21). The same group also found an activating GNAS mutation in 9 of 30 patients with JGCT (15). Bessière et al (14) found, in 10 of $16 \mathrm{JGCT}$ patients, in-frame duplications in exon 3 of the oncogene $A K T 1$ which lead to its activation. Given that analysis of exon 3 in AKT1 was negative in our case, whole gene sequencing would be the next diagnostic step in seeking a molecular genetic cause for JGCT. However, given the time and expense involved, this measure would be difficult to justify in an individual patient.

To investigate a putative link between MAS and JGCT, we have examined gene expression in adrenal tissue bearing activating GNAS1 mutations (Geo Dataset GSE33694 ref PMID: 22259056), and in ovarian tissue from patients with JGCT (22). Interestingly, both the tissues studied showed significant enrichment in genes which are significantly dysregulated by overexpression of the proto-oncogene B-Raf (adjusted p value 0.002 for the directly expressed McCune-Albright genes and $<0.001$ for the directly expressed JGCT genes). B-Raf is known to be phosphorylated by the AKT1 gene and also to be differentially regulated by cAMP-dependent protein kinase A activation, which is itself dependant on GNAS1 activity. Further work examining the interplay between B-Raf, GNAS1 and AKT genes might clarify a possible link between MAS and JGCT.

In practical terms, our patient requires continuing follow up in case other features of MAS develop, paying special attention to the morphology of her remaining ovary. Critical attention is also needed to growth rate and pubertal status, given the risk of developing true central precocious puberty through previous exposure to raised sex steroid levels-the phenomenon of "priming". Fortunately, more than five years since the tumour was successfully removed, our patient remains prepubertal with height now in the lower half of the normal centile range and only marginal bone age advance.

Finally, a puzzling aspect of our case for which we have no explanation is the mild, but consistent, elevation of basal LH observed throughout, with a paradoxical drop from 0.43 to $0.18 \mathrm{mIU} / \mathrm{mL}$ after LHRH administration at initial presentation. Since successful surgery, mild basal LH elevation has persisted at a level suggestive of true central puberty. Despite this, the patient has remained clinically prepubertal since surgery, with normal oestradiol values for age.

\section{Acknowledgements}

We gratefully acknowledge assistance from Mrs. Morag Green from the Royal Hospital for Sick Children in Edinburgh, Scotland with the interpretation and labelling of the radiology figures, and to Mark Whittington for his help with preparing the figures. We also thank the patient's family for allowing us to publish their daughter's case and agreeing to genetic analysis in London and Paris.

\section{Ethics}

Informed Consent: Consent for genetic analysis and publication of the case was obtained from the parents.

Peer-review: Externally peer-reviewed.

\section{Author Contributions}

Surgical and Medical Practices: Hager Barakizou, Souha Gannouni, Thouraya Kamoun, Fernanda Amary, Reiner Veitia, Concept: Hager Barakizou, Design: Hager Barakizou, Reiner Veitia, Data Collection or Processing: Hager Barakizou, Souha Gannouni, Thouraya Kamoun, Analysis or Interpretation: Hager Barakizou, Souha Gannouni, Thouraya Kamoun, Fernanda Amary, Zilla Huma, AnneLaure Todeschini, Reiner Veitia, Malcolm Donaldson, Literature Search: Hager Barakizou, Zilla Huma, Anne-Laure Todeschini, Reiner Veitia, Malcolm Donaldson, Muhammed Mehdi, Writing: Hager Barakizou, Zilla Huma, Anne-Laure Todeschini, Reiner Veitia, Malcolm Donaldson.

Financial Disclosure: The authors declared that this study received no financial support.

\section{References}

1. Donaldson MDC, Gregory JW, Van Vliet G, Wolfsdorf J. Puberty. in: Practical Endocrinology and Diabetes in Children. 4th ed. WileyBlackwell, 2019;115-142.

2. de Silva KS, Kanumakala S, Grover SR, Chow CW, Warne GL. Ovarian Lesions in Children and Adolescents -- An 11-year Review. J Pediatr Endocrinol Metab 2004;17:951-957

3. Lumbroso S, Paris F, Sultan C; European Collaborative Study. Activating Gs $\alpha$ mutations: analysis of 113 patients with signs of McCune-Albright syndrome--a European Collaborative Study. J Clin Endocrinol Metab 2004;89:2107-2113.

4. Dumitrescu CE, Collins MT. McCune-Albright syndrome. Orphanet J Rare Dis 2008;3:12.

5. Collins MT, Chebli C, Jones J, Kushner H, Consugar M, Rinaldo P, Wientroub S, Bianco P, Robey PG. Renal Phosphate Wasting in Fibrous 
Dysplasia of Bone is Part of a Generalized Renal Tubular Dysfunction Similar to That Seen in Tumor-Induced Osteomalacia. J Bone Miner Res 2001;16:806-813.

6. Kirk JM, Brain CE, Carson DJ, Hyde JC, Grant DB. Cushing's syndrome caused by nodular adrenal hyperplasia in children with McCuneAlbright syndrome. J Pediatr 1999;134:789-792.

7. Salenave S, Boyce AM, Collins MT, Chanson P. Acromegaly and McCuneAlbright Syndrome. J Clin Endocrinol Metab 2014;99:1955-1969. Epub 2014 Feb 11

8. Mastorakos G, Mitsiades NS, Doufas AG, Koutras DA. Hyperthyroidism in McCune-Albright syndrome with a review of thyroid abnormalities sixty years after the first report. Thyroid 1997;7:433-439.

9. Javaid MK, Boyce A, Appelman-Dijkstra N, Ong J, Defabianis P, Offiah A, Arundel P, Shaw N, Pos VD, Underhil A, Portero D, Heral L, Heegaard AM, Masi L, Monsell F, Stanton R, Dijkstra PDS, Brandi ML, Chapurlat R, Hamdy NAT, Collins MT. Best practice management guidelines for fibrous dysplasia/McCune-Albright syndrome: a consensus statement from the FD/MAS international consortium. Orphanet J Rare Dis 2019;14:139.

10. Horta M, Cunha TM. Sex cord-stromal tumors of the ovary: a comprehensive review and update for radiologists. Diagn Interv Radiol 2015;21:277-286.

11. Shah SP, Köbel M, Senz J, Morin RD, Clarke BA, Wiegand KC, Leung G, Zayed A, Mehl E, Kalloger SE, Sun M, Giuliany R, Yorida E, Jones S, Varhol R, Swenerton KD, Miller D, Clement PB, Crane C, Madore J, Provencher D, Leung P, DeFazio A, Khattra J, Turashvili G, Zhao Y, Zeng T, Glover JN, Vanderhyden B, Zhao C, Parkinson CA, JimenezLinan M, Bowtell DD, Mes-Masson AM, Brenton JD, Aparicio SA, Boyd N, Hirst M, Gilks CB, Marra M, Huntsman DG. Mutation of FOXL2 in granulosa-cell tumors of the ovary. N Engl J Med 2009;360:2719-2729. Epub 2009 Jun 10

12. Young RH. Sex Cord-Stromal, Steroid Cell, and Other Ovarian Tumors with Endocrine, Paraendocrine and Paraneoplastic Manifestations. In: Kurman RJ, Ellenson LH, Ronnett BM (eds). Blaustein's pathology of the female genital tract 6th ed. New York, London. Springer, 2011;785846.

13. Young RH, Dickersin GR, Scully RE. Juvenile Granulosa Cell Tumor of the Ovary. A Clinicopathological Analysis of 125 cases. Am J Surg Pathol 1984;8:575-596.
14. Bessière L, Todeschini AL, Auguste A, Sarnacki S, Flatters D, Legois B, Sultan C, Kalfa N, Galmiche L, Veitia RA. A hot-spot of in-frame duplications activates theb oncoprotein AKT1 in juvenile granulosa cell tumors. EBioMedicine 2015;2:421-431.

15. Kalfa N, Ecochard A, Patte C, Duvillard P, Audran F, Pienkowski C, Thibaud E, Brauner R, Lecointre C, Plantaz D, Guedj AM, Paris F, Baldet P, Lumbroso S, Sultan C. Activating mutations of the stimulatory G protein in juvenile ovarian granulosa cell tumors: a new prognostic factor? J Clin Endocrinol Metab 2006;91:1842-1847. Epub 2006 Feb 28

16. Sempe M, Pédron G, Roy-Pernot MP. Auxology, methods and sequences. In: Auxologie, Methode et sequences. Paris, Theraplix, 1979.

17. Greulich WW, Pyle SI, Waterhouse AM. A radiographic standard of reference for the growing hand and wrist. Case Western Reserve University, Chicago, 1971.

18. Idowu BD, Al-Adnani M, O’Donnell P, Yu L, Odell E, Diss T, Gale RE, Flanagan AM. A sensitive mutation-specific screening technique for GNAS1 mutations in cases of fibrous dysplasia: the first report of a codon 227 mutation in bone. Histopathology 2007;50:691-704.

19. Foster CM, Feuillan P, Padmanabhan V, Pescovitz OH, Beitins IZ, Comite F, Shawker TH, Loriaux DL, Cutler GB Jr. Ovarian Function in Girls with McCune-Albright Syndrome. Pediatr Res 1986;20:859-863.

20. Ye Y, Lv C, Xu S, Chen Y, Qian R, Wang P, Wang S. Juvenile Granulosa Cell Tumors of the Ovary. Am J Clin Pathol 2020;154:635-644.

21. Kalfa N, Philibert P, Audran F, Ecochard A, Hannon T, Lumbroso S, Sultan C. Searching for somatic mutations in McCune-Albright syndrome: a comparative study of the peptidic nucleic acid versus the nested PCR method based on 148 DNA samples. Eur J Endocrinol 2006;155:839843.

22. Auguste A, Bessière L, Todeschini AL, Caburet S, Sarnacki S, Prat J, D’angelo E, De La Grange P, Ariste O, Lemoine F, Legois B, Sultan C, Zider A, Galmiche L, Kalfa N, Veitia RA. Molecular analyses of juvenile granulosa cell tumors bearing AKT1 mutations provide insights into tumor biology and therapeutic leads. Hum Mol Genet 2015;24:66876698. Epub 2015 Sep 11 